\title{
QUASI-MENTAL RETARDED REPRESENTED IN SPEECH ACT OF FORREST'S UTTERANCES IN FORREST GUMP MOVIE
}

\section{AN ARTICLE}

Submitted as Partial Fulfillment of the Requirements

For the Degree of Sarjana Sastra

By:

FEISAL MUHAMMAD

Registration Number: 2121220005

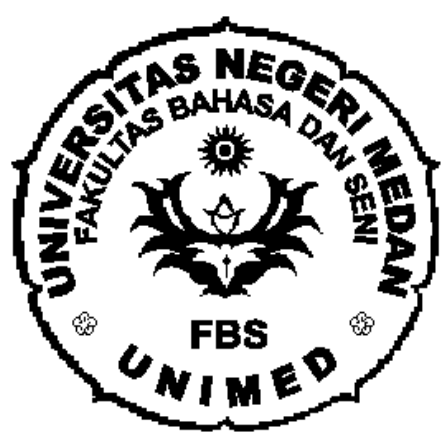

ENGLISH LITERATURE DEPARTMENT

FACULTY OF LANGUAGE AND ARTS STATE UNIVERSITY OF MEDAN 


\section{ARTIKEL \\ QUASI-MENTAL RETARDED REPRESENTED IN SPEECH ACT OF FORREST'S UTTERANCES IN FORREST GUMP MOVIE}

Disusun dan Diajukan oleh :

Feisal Muhammad

NIM.2121220005

Telah diverifikasi dan dinyatakan memenuhi syarat untuk diunggah pada jurnal online

Medan, Februari 2017

Menyetujui

Dosen Pembimbing Skripsi I

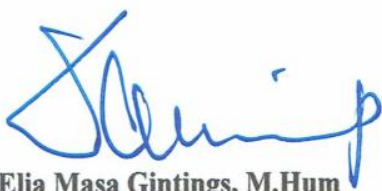

Drs.Elia Masa Gintings, M.Hum NIP.19580707 19850310017
Dosen Pembimbing Skripsi II

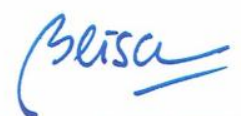

Elisa Betty Manullang,S.S,M.Hum NIP.19751114 2008122001

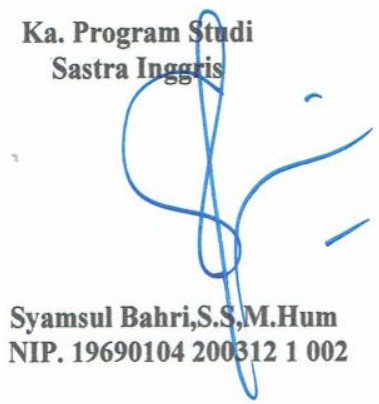




\title{
Quasi-Mental Retarded Represented in Speech Act of Forrest's Utterances in Forrest Gump Movie.
}

\author{
*Feisal Muhammad \\ * Drs. Elia Masa Gintings, M.Hum. \\ *Elisa Betty Manulang,S.S,M.Hum
}

\begin{abstract}
Muhammad, Feisal. 2121220005. Quasi-Mental Retarded Represented in Speech Act of Forrest's Utterances in Forrest Gump Movie. A Thesis. Faculty of Languages and Arts. State University of Medan. 2016.

The study entitled Quasi-Mental Retarded Represented in Speech Act of Forrest's Utterances in Forrest Gump Movie. The objectives of the study were to find out the types of speech acts found in Forrest's utterances of Forrest Gump Movie and to describe the function speech acts were used by main character that had a mental retardation. The study was conducted by applying descriptive qualitative design. The data of the study were utterances that used by main character in Forrest Gump movie, and there were 620 utterances found in Forrest's utterances. Yule's theory deals with types of speech acts were applied to analyze the data. The findings of the study showed that the types of speech acts were realized in Forrest's utterances with the ratio; Declaration acts were 24 (3,87\%), Representative acts were 443 (71,45\%), Expressive acts were 44 (7,11\%), Directive acts were 85 (13,70\%) and Commissive acts were $24(3,87 \%)$. The representative acts was one of speech acts type that most dominant uttered by Forrest in Forrest Gump Movie. It showed that mental retardation disorder wanted to represent a world as they believe.
\end{abstract}

Keywords:types of speech acts, mental retardation disorder 


\section{INTRODUCTION}

Language is one of important tool to do a communication or interaction the two ways. It influences human life as the bridge to have relationship with other people or society. Utterances are one of the way use a language so ideas, messages and intentions can be delivered to another person. However, sometimes the people do an interaction two ways through unstructured utterances communication. Actually there is no problem because the most important thing is how their utterance can deliver a meaning and can be accepted by another one. People do not only produce utterances containing grammatical structures sentences and words, but they should that shows action in their utterances or speech so that their meaning or desire can be delivered to another one. (Yule, 1996:47)

Speech acts means a study about saying and doing. It means that someone does not only simply say the words but he or she also at the same time uses them to do things. Speech acts perform when people makes an utterances such as apology, greeting, request, complain, invitation, compliment and refusal. Actually, speech act study is importance for everyone. The one importance of studying speech act is to make someone can comprehend what message has been interpreted in every utterance of speaker. It can be called speech if there is an ability of language which is owned by speaker to convey their messages in communication. The listener can interpreted their messages appropriate context of 
speaker. To make clear about the meaning from utterance which speaker said, Yule (1996:53) has made a one general classification system lists five types of general functions performed by speech acts. They are declarations, representative, expressive, directive, commissives. Here, writer will explain about five type of general functions is performed by speech act. The first is declarations are statements which change the state something in the world through utterances. Second is representatives are statement which describe or explain about true event in the world through utterances. Third is expressive are statement which express about inner of speaker like thanking, apologizing, welcoming, joy, like, dislike complaining etc.

Forrest Gump is one movie which is a romantic-comedy-drama genre at 1994 by Robert Zemeckis. It tells about a story a man who name is a Forrest. Forrest has a disorder which its name is mental retardation disorder. Mental Retardation disorder is a particular state of functioning that begins in childhood and is characterized by decreased intelligence and adaptive skills and also is the most common developmental disorder. It means that this disorder will be formed someone be a character who has decreased intelligence. Immediately, it will disturb the process of conversation to listener because there is misunderstanding meaning between speakers to listener. Every utterance of this character who has a mental retardation disorder in Forrest Gump movie is suitable to analyze through 
pragmatics study, especially based on speech act theory because speech act is study about how to meaning of speaker is interpreted by listener.

The writer will explain that this study focuses on analyzing the function types of speech act based on Yule categories general function in every utterances of Forrest in Forrest Gump Movie. The writer choose speech acts theory because the writer ever study speech acts in the class, and this study discusses deal with meaning, in addition learn about how speaker delivers message and then interpreted by listener. This study will explain how do type function of speech act are used by mental retardation disorder of Forrest in Forrest Gump Movie

\section{Pragmatics}

Pragmatic is the study of speaker meaning. It refers that is meaning of speaker can be interpreted by listener. Yule (1996:3) says that Pragmatic is a concerned with the study of meaning as communication by speaker (or writer) and interpreted by a listener (or reader). On the other hand, Mey (1993:6) states that pragmatics as study of the way humans use their language in communication, bases itself on a study of those premises and determines how they affect, and effectualized, human language use. This study is to analyze an utterance of speaker so listeners know about meaning of speaker's utterance.

\section{Speech Act}

Every people generally produce utterance to deliver a sentence to another people. It contains a grammatical and structure words in every sentences. They 
actually perform their action via their utterances in order to their meaning can be delivered. Action performed via utterances are generally called speech act (Yule, 1996:47). On the other hand, Mey (1994:111) states that speech acts are actions happening in the world, that is, they bring about a change in the existing state of fair.

\section{a. Locutionary Act}

A locutionary act is an act of how a person produces the utterance or to produce a meaningful linguistics expression. Yule (1996:48) states that Locutionary act is the basic of utterances or producing a meaningful linguistic expression.

\section{b. Illocutionary Act}

In every utterance, there must be a function in it. The function which is found in the utterances is called the illocutionary act. Yule (1996:48) states that illocutionary act is performed via the communicative force of an utterance.

\section{Classification of Speech Act}

Yule states that one general classification system lists five types of general functions performed by speech acts verb: declarations, representatives, expressives, directives, and commissives. 


\section{a. Declarations}

Declaration is kind of speech act that effect immediate changes in some changes in some current state of affairs. It brings the effect to change the state affairs in the world, like declaring, war, firing, marrying, bidding and etc.

\section{b. Representatives}

Representatives are those kinds of speech act that commit the speaker to the truth of the expressed proposition. They express the speaker's belief.

\section{c. Expressive}

Expressive are those kinds of speech act that express a psychological attitude or state in the speaker such as joy, sorrow, like/dislikes, thanking, apologizing, welcoming, complaining, deploring, and congratulating.

\section{d. Directive}

Directives are those kinds of speech act that represent attempts by the speaker to get the addressee to do something.

\section{e. Commissives}

Commissives are those kinds of speech act that commit the speaker to some future course of action.

\section{Literature}

Literature is one of a thing which has a meaning, feeling and desire is formed in the novel, poetry, film etc. Meyer (1997:1) states that literature is prototypical characteristics include careful use of language, being written in a 
literary genre (poetry, prose fiction, or drama), being read aesthetically, and containing many weak implicate.

\section{a. Movie}

Movie is one the part of literature. It usually tells an event which it is not real but can be a representation in daily's life because usually the story is taken from real life and then retell again be a movie.

\section{b. Character}

Concept of create a person for a narrative. It is a literary element and may be employed in dramatic works of art or everyday conversation.

\section{Mental Retarded}

This is indication of Mental Retarded. Bregman in Armatas (1991:114) states that mental retardation is a particular state of functioning that begins in childhood and is characterized by decreased intelligence and adaptive skills and also is the most common developmental disorder. MR retardation in young children is often missed by clinicians. The condition is present in 2 to 3 percent of the population, either as an isolated finding or as part of a syndrome or broader disorder 


\section{RESEARCH METHODOLOGY}

Research will typically include how data is to be collected, how the instruments will be employed, how the instruments will be used and the intended means for analyzing data collected. This research will be conducted by applying descriptive qualitative method which does not intend to find new theory but to find new evidence to prove the truth theory. Qualitative research is one research procedure that will produce descriptive data in form of written and spoken words from people's behavior that can be research. Ary at all (2002:25) states that Qualitative researchers seek to understand a phenomenon by focusing on the total picture rather than breaking it down into variables.

The purpose of study is focusing on analyzing the function types of speech act based on Yule categories general function in every utterances of Forrest in Forrest Gump Movie. The writer choose speech acts theory because the writer ever study speech acts in the class, and this study discus deal about meaning, in addition learn about how speaker delivers message and then interpreted by listener . This study will explain how do type function of speech act are used by mental retardation disorder of Forrest in Forrest Gump Movie.

\section{A. Source of Data}

The source of Data for study will be taken from : 
The most important thing in this research is the accuracy of the data. By using the accurate data, we will get the more an accurate data.

The source data of this study is a movie entitled Forrest Gump directed by Robert Zemeckis. The data in this study were collected from the utterances spoken in dialogue and monologue by Forrest as the main character in this movie. To support the main data of this study the writer takes a movie transcript and needs much information from textbooks and other sources. Such as internet, encyclopedias, and some relevant written materials which discuss about mental retarded represented in speech act by character in the movie or in the reality.

\section{B. Technique for Collecting Data}

The technique for collecting data is a method which is needed to get information and make a goal of study. The writer used some steps in collecting the data. The steps are as follows:

1. Watching the movie to get an information about character especially main character, Forrest Gump

2. Download a transcript of Forrest's utterances in Forrest Gump movie the way using an internet.

3. Checking the accuracy between Forrest's utterance in transcript with his utterance in the movie

4. Selecting the data from Forrest Gump Movie which were in accordance with the objectives of the study. 
5. Recording the data into data sheet.

\section{Technique of Analyzing Data}

There were several steps of analyzing the data. The steps of the analysis include:

1. Identifying the data which collected from the dialogue in script

2. Applying the theories related to the problem and anything needed based on the purpose of the study. In this case, the researchers use speech act theory based on Yule

3. Identifying and finding out type function of speech act in every Forrest's utterances based on Yule theory.

4. Explaining how type function of speech acts are used Quasi-mental retarded of Forrest after finding out dominant of type function of speech act.

5. Count the percentage of each type of speech act from Forrest's utterances by the mathematic formula.

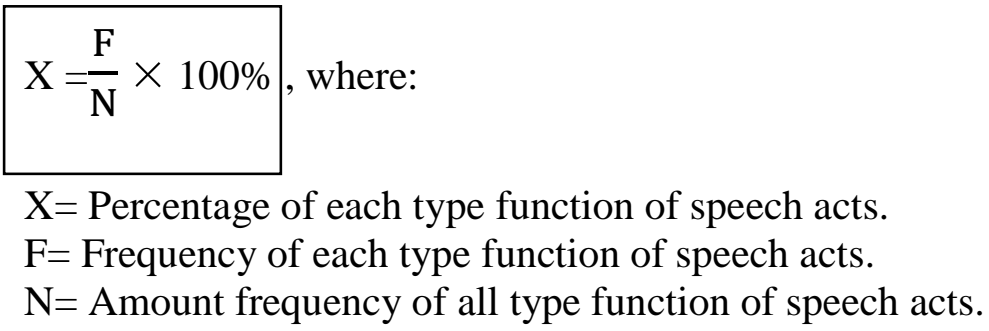

6. Making conclusion from the data analyzed. 


\section{CONCLUSION AND SUGGESTION}

\section{A. Conclusions}

Based on the findings of the research, it can be concluded that:

1. There are five types of speech acts namely; declarations $24(3,87 \%)$, representative $443(71,45 \%)$, expressive $44(7,11 \%)$, directives $85(13,70 \%)$ and commissive $24(3,87 \%)$ are applied in Forrest Gump's utterances.

2. The representative type is the most dominant uttered by main character Forrest Gump in Forrest Gump. It is $443(71,45 \%)$

3. From the previous analysis, it can be seen that representatives generally used by Forrest Gump who has a mental retardation in Forrest Gump Movie. It shows that mental retardation disorder wants to represent a world as they believe to share to listener. They always convey what they know about a fact despite on listener does not like what they uttered. It also shows that mental retardation does not see what listener understand about speaker's belief. For them, especially mental retardation disorder, they just utter what they know or believe without seeing their around. 


\section{B. Suggestion}

In relation to the conclusion above, some suggestions are given as bellow:

1. It is suggested that the people who wants to learn about speech act especially for reader this thesis know how important speech act is used in communication especially to avoid the misunderstanding communication.

2. For other researcher, this research could be one reference in studying about speech act. Especially for researcher wants to relate this study with another knowledge.

3. For society, this research will give any information about main character in Forrest Gump movie. It can help the society how the language is used by main character in general communication. 


\section{REFERENCES}

Akinwotu.2013."Speech Act Analysis of the Acceptance of Nomination Speeches of Chief Obafemi Awolowo and Chief M.K.O Abiola”. English Linguistic Research. Vol.2. p $1-9$

Armatas.2009. "Mental Retardation: Definitions, Etiology, Epidemiology, and Diagnosis".Journal of Sport and Health Research. Vol.1.2. p 112-121

Ilyas,S., and Kushi,Q.2012. "Facebook Status Updates : A Speech Act Analysis". Academic Research International. Vol 3. (2). P 1 - 8

Isnawati,f., and et all.2015. "Speech Act Analysis of the Main Character in Shrek Movie Script". Publika Budaya.Vol.1. (3).P 60 - 64

Mey,J.L. 1994. Pragmatics : an introduction .London : Basic Blackwell

Meyer, J.1997. "What is a Literature".Work Papers of the Summer Institute of Linguistic.Vol.41. p 1-10

NICHCY.2013. "Mental Retardation”. National Information for Children and Youth with Disabilities.p.1-4

Roy,B.2011. "Adjustment Problems of Educable Mentally Retarded”. International Journal of Scientific and Research Publication.Vol.2.p 1-5

Rui,Y.2014. “The Influences of Forrest Gump's Characters on His Language Characteristics in Film Forrest Gump". Canadian Social Science.Vol.10.p 221-228

Yule,G.1996. Pragmatic. Oxford: Oxford University Press 